\title{
Effects of Chinese Development Aid on International Human Rights: Analysis of UN Votes (2001-2013)
}

\author{
Linnea M. Dulikravich \\ University of Florida \\ Faculty Mentor: Aida Hozic, Department of Political Science
}

\begin{abstract}
Chinese investments have raised concerns, especially in the United States and European Union, because of their size but also because of their lack of political conditionality. Unlike Western aid, which is usually accompanied with demands for democratization, transparency and the rule of law, Chinese investments make no such demands on the host governments. Given China's lack of respect for human rights, at least in the eyes of the West, there are also concerns that development aid from the BRI might be detrimental for human rights in recipient countries. This study analyzes the voting record of human rights resolutions in the UN from 2001-2013 for countries that have received substantial aid from China as a part of the Belt and Road Initiative (BRI). The data shows that recipient countries are likely to align their UN votes with China, but not necessarily to the detriment of human rights. Close analysis of the resolutions passed by BRI partner countries show that most of their votes affirm human rights, which does not support the expectation that Chinese aid has a negative impact on the existing global human rights regime.

Keywords: Belt and Road Initiative, human rights, United Nations, international development
\end{abstract}

\section{Introduction}

Reliable infrastructure is crucial to spurring economic growth. Through China's Belt and Road Initiative (BRI), developing countries around the world are acquiring massive Chinesebacked loans to fund infrastructure projects with the hopes that increased trade opportunities will soon follow. Concerns about the BRI have often focused on the economic implications of these loans, such as whether debts incurred from these partnerships are sustainable or merely a modern form of economic imperialism. Nevertheless, there is reason to believe that these loans have social implications of possible concern to the international community, including how does debt to China influence countries' international political support for issues of human rights?

One way that international laws, including international human rights law, are created is through passing resolutions in the United Nations General Assembly (UNGA). Because the UNGA needs a majority to pass resolutions, scholars and politicians alike might be skeptical 
about the intentions motivating a major world power to launch an initiative where "more than sixty countries - accounting for two-thirds of the world's population - have signed on to projects [using development loans from China's BRI] or indicated an interest in doing so" (Chatzky \& McBride, 2019).

Due to China's economic footprint, there is concern that the Chinese may be able to influence human rights policy globally. This is concerning because China's human rights record has been deemed questionable by many Western academics and politicians. With more countries joining China's BRI every year, there are more United Nations member countries becoming increasingly indebted to China. This also means that the international system's ability to create or amend human rights laws are increasingly becoming dependent on the votes of countries benefitting from Chinese-funded development projects. Therefore, there is a compelling need to analyze whether China's unilateral loans strategy has been an effective diplomatic tool to decrease BRI partner countries' tendency to support human rights resolutions in the UN General Assembly.

To analyze whether debt to China is influencing international political support for issues of human rights, this study evaluates 54 BRI countries over time according to their United Nations votes and CFR index of debt to China scores. Specifically, voting data from the UN digital library is used to calculate each countries' probability of agreeing with China's vote (based on voting alliance each year) as well as to calculate each countries" average "yes" votes (based on the number of Yes votes divided by the total number of human rights-related resolutions each year). This article explores two hypotheses. The first hypothesis being tested is that the BRI partner countries' CFR Index of Debt to China (as percent of GPD) is a positive indicator of whether they will vote in alliance with China in the United Nations on human rights resolutions. This vote analysis over the years of 2001-2013 shows that the probabilities of 54 BRI partner countries' voting alliance with China were positively associated with each countries' debt to China. This is consistent with previous studies showing that development aid does influence votes in the United Nations.

The second hypothesis expands on this finding by testing if BRI partner countries are less likely to pass human rights resolutions because of their alliance with China. Perhaps surprisingly, this analysis revealed a positive association with each countries' average "yes" votes on UN human rights resolutions and probabilities of coinciding votes with China. This correlation 
suggests that voting in agreement with China increases international support for human rights advancement. If this is so, this could be evidence that Westerners' perceptions of China as "antihuman rights" is simply an outdated Western bias and not reality. Hypothesis testing for both hypothesis 1 and 2 was conducted using correlation, probability tabulation, and regression.

\section{Literature Review and Theory}

Existing literature tends to agree with the general conclusion that countries receiving development aid from multilateral institutions will more frequently align their UN votes with the votes of the countries sponsoring that aid. One study, "Do the IMF and the World Bank influence voting in the UN General Assembly?" (Dreher \& Sturm 2012), analyzes UN voting patterns of countries receiving IMF and World Bank loans over the period of 1970-2008. Instead of comparing countries' votes to China's vote, empirical evidence in this study focuses on Western influence by analyzing countries' votes in coincidence with the United States' vote. It found that there is a significant pattern indicative of loan recipients voting "more frequently in line with the average G7 country" (Dreher \& Sturm, 2010). This leads the author to hypothesize that BRI partner countries would more frequently vote in line with China in the UN General Assembly on issues of human rights.

Another study, "Does US aid buy UN general assembly votes? A disaggregated analysis" (Dreher, Nunnenkamp \& Thiele, 2008), asks the same empirical question that this paper explores, but in the context of unilateral U.S. aid rather than Chinese aid. It conducts an analysis comparing US aid with recipients' UN voting data from 1973-2002. It found that there is "strong evidence that US aid buys voting compliance in the Assembly" (Dreher, Nunnenkamp \& Thiele, 2008). Interestingly, no comparable patterns emerge when this empirical analysis was replicated for the other G7 donors (France, Japan, Italy, Canada, Germany, and the United Kingdom), which do not provide as robust aid as the US does. This leads the author to hypothesize that BRI partner countries' votes might only coincide with China's vote if they are receiving significant amounts of aid. These two studies suggest the following hypothesis on voting alliance.

\section{Hypothesis 1: Voting Alliance}

Existing literature on human rights have reached conflicting conclusions about the impact of $\mathrm{UN}$ resolution votes on the tangible advancement of human rights. Human rights resolutions are an overlooked, but real policy area of consequence. One study, the "Human Rights and Development: a Comment on Challenges and Opportunities from a Legal Perspective" 
(McInerney-Lankford, 2009), established that "human rights are not voluntary or just rhetorical, they are the subject of legally binding commitments". This implies that voting "yes" on human rights resolutions in the UN General Assembly will make it more likely for those rights to be treated as legitimate international law by the international community. If so, this would suggest that voting neutrally or voting against UN resolutions that promote human rights could be perceived as an act of human rights opposition.

Given China's questionable history on human rights, it is understandable why academics might believe China's change of heart in support of human rights would be primarily for political purposes as a diplomatic tool. In "Human Rights and the Uses of History" (Moyn, 2017), academics like David Rieff believe that human rights advancement now stands "revealed as an ideology perfectly designed to cloak to 'military humanism' of empire." This argument goes on to explain how diplomatic, yet hollow, promises in support of human rights is nothing more than a grand strategy of economic domination.

On the other hand, the United Nations itself was founded by countries largely following ideals defined by the West. Therefore, it is possible that China might not vote in favor of Western societies' concepts of "human rights" when they are not aligned with China's cultural beliefs. One paper published by Russian scientists articulates some of basic features of Chinese human rights beliefs as the following:

- "Priority of collective rights over individual rights: from antiquity to the present, human rights are basically defined as collective rights rather than rights of a man. The term 'man' refers to the singular 'entity' of people rather than individuals, i.e. no individual can claim his human rights to protest against the status quo;

- Priority of civil rights over human rights: the latter are to be recognized by the authorities and not to be claimed by or for oneself; moreover, 'rights' only exist as something given by the state" (Tsvyk \& Tsvyk, 2019).

These tenets suggest that BRI countries' votes "for" human rights in the UN are not simply a result of debt to China, but rather they are based on cultural similarities with China's societal beliefs. Moreover, these countries' willingness to join the BRI could be evidence that these countries already felt aligned with China on a diplomatic level about issues like human rights even prior to receiving development loans. These three papers suggest the following hypothesis on BRI partner countries' support for "human rights" as currently defined by the UN. 


\section{Hypothesis 2: Support for "Human Rights"}

The higher their tendency to vote "yes" in the United Nations on resolutions advancing human rights, the less likely BRI partner countries are to vote the same way as China.

\section{Data and Methods}

Hypothesis testing for both hypothesis 1 and 2 was conducted using correlation, probability tabulation, and regression to assess how closely related the variables are. To determine the impact of the BRI on UN voting in this hypothesis, this paper draws on UN voting data from Erik Voeten's dataset on Harvard dataverse. From his dataset, the years prior to 2001 are dropped due to unavailability of CFR debt ratio data prior to then, and the years evaluated end at 2013, which is the last year of UN voting data available from the Harvard dataverse set. Then, only those UN votes related on resolutions pertaining to "human rights advancement" were kept, and the rest deleted.

To determine which resolutions pertain to human rights, one can sort resolutions listed in the UN Digital Library by the "human rights advancement" category. All of Voeten's data originally came from the UN Digital Library, which provides member countries' voting records on all UN General Assembly resolutions since the United Nations was formed. After dropping all countries' votes except for the remaining BRI partner countries, the resulting dataset was a list of "YES", "NO", and "ABSTAIN" voting records for a total of 54 BRI partner countries on 135 human rights-related resolutions over the years of 2001-2013. Lastly, the text file containing "YES", "NO", and “ABSTAIN" data was destringed and replaced with "1", "0", and " 0 ", respectfully. The reason why "NO" and "ABSTAIN" are both counted the same is because this paper focuses only on votes that actively support the advancement of human rights, and therefore a neutral abstention would not theoretically be evidence of human rights support.

The dependent variable used in Hypothesis 1 and 2 (DV) is referred to in tables as "ProbChinaAgree" and is coded for each BRI partner country as the portion of their votes each year that aligned with China's vote on human rights-related UN resolutions (hence, the "probability that they agreed with China's vote"). To create this variable, the variable "CountChinaAgree" was first made to count the number of resolutions in a year for which a BRI country's vote aligned with China's vote. "ProbChinaAgree" was then coded as the percentage of "CountChinaAgree"/total number of human rights-related resolutions that year. The result is a decimal between 0 and 1. The independent variable used in Hypothesis 1(IV1) is BRI countries' 
CFR Index of Debt to China (as percent of GPD). Then, the "CFR Index of Debt to China" values for all BRI countries for each year (2001-2013) was used from an article published by the Council on Foreign Relations. This CFR index is an estimate of countries' external debt to China as a percent of their national GDP. It includes debt from three types of Chinese investment: portfolio investment, development loans, and foreign direct investment.

To create this lower-bound, conservative index, the Council on Foreign Relations analyzed publicly available sources such as media reports and government statements discussing Chinese development loans. "A loan is not included if it has only been pledged or agreed upon in a memorandum of understanding" (Steil \& Della Rocca, 2019). This method is used to ensure the specific amount of loans that are disbursed, not merely promised. Development loan data used to make this index came from a combination of sources: "AidData at the College of William and Mary, the Export-Import Bank of the United States, the Center for Strategic and International Studies, the Export-Import Bank of China, the China Africa Research Initiative at Johns Hopkins University's School of Advanced International Studies, country governments, multilateral development banks, and third-party media sources" (Steil \& Della Rocca, 2019). To calculate this index as a percentage of GDP, the Council on Foreign Relations used GDP data from the International Monetary Fund.

To test the second hypothesis, that countries with tendencies to vote "yes" in the UN also tend to vote differently than China, a novel measurement of agreement had to be created. The independent variable used in Hypothesis 2 (IV2) is coded "AverageYes". This variable measures each BRI countries' percent of "yes" votes on all human rights-related resolutions that year (hence, the "annual average of yes votes"). This was just a matter of calculating a simple average across all resolution votes for each given year. Since votes are recorded as "0"s and "1"s, the result for "AverageYes" is also a value between 0 and 1 .

After researching, collecting, coding, reshaping, and doing some calculations with the data, some preliminary testing was done for each hypothesis. For Hypothesis 1, the correlation between "ProbChinaAgree" and the "debtratio" was found to be 0.1982, as shown below. Though a correlation coefficient of 0.1982 indicates a positive correlation between the two variables, it is moderately weak. This suggests that international development financing through China's Belt and Road Initiative is not as strong of an indicator of United Nations alliance as western scholars and politicians may have feared. 
Table 1: Correlation between Voting in Alliance with China and Debt to China

\begin{tabular}{c|l|l} 
& probchinaagree & debtratio \\
\hline probchinaagree & 1.0000 & \\
\hline debtratio & 0.1982 & 1.0000
\end{tabular}

For Hypothesis 2, however, the correlation between "ProbChinaAgree" and "AverageYes" was found to be 0.9121 , as shown below. This is a very strong positive correlation, suggesting that voting in alliance with China increases the likelihood that BRI partner countries are voting to pass human rights resolutions, which might come as a surprise to western scholars and politicians.

Table 2: Correlation between Voting Yes and Voting in Alliance with China

\begin{tabular}{c|l|l} 
& probchinaagree & averageyes \\
\hline probchinaagree & 1.0000 & \\
\hline averageyes & 0.9121 & 1.0000
\end{tabular}

Though these correlation results seem to provide some support for Hypothesis 1, it appears that the correlation for Hypothesis 2 was much higher than existing academic literature would have predicted. These findings were further illuminated by using summaries of "debtratio" for Hypothesis 1 during years 2001 and 2013, and tabulations of "ProbChinaAgree" and "debtratio" for Hypothesis 1 during years 2001 and 2013. Then, the number of countries whose "debtratio" were higher than the mean in each year and whose "ProbChinaAgree" value was also higher than $50 \%$ was tallied. This tally was compared to tabulations of "ProbChinaAgree" and “AverageYes” for Hypothesis 2 during years 2001 and 2013. Then, the number of countries whose "AverageYes" scores were higher than 50\% and whose "ProbChinaAgree" value was also higher than $50 \%$ was tallied. Below is a chart summarizing these results:

Table 3: Probabilities of Voting “yes” vs. Agreeing with China (2001 \& 2013)

\begin{tabular}{c|c|c}
$\begin{array}{c}\text { Votes in Alignment with China 50\% or more of the } \\
\text { time }\end{array}$ & $\begin{array}{c}\text { Above-average Debt } \\
\text { Ratio }\end{array}$ & $\begin{array}{c}\text { Votes "yes" } 50 \% \text { or more of the } \\
\text { time }\end{array}$ \\
\hline in 2001 & 6 & 28 \\
\hline in 2013 & 11 & 35
\end{tabular}


From this analysis, one can observe that the amount of BRI countries that voted in agreement with China 50\% or more of the time increased between 2001 and 2013. One also will notice that the amount of BRI countries with above-average debt to China increased from 2001 to 2013, as did the amount of countries with $50 \%$ or higher probability of voting "yes". This seems to confirm Hypothesis 1 that higher debt is associated with a higher likelihood of voting in agreement with China. However, the increase in voting "yes" on resolutions related to human rights issues seems to contradict Western beliefs that China is "anti-human rights". This chart and related tables, however, do not explain the statistical significance of the relationships between the variables, nor does it control for any variables. This test also does not show any sort of regression line that could be used to predict values if given the CFR Debt to China ratio or UN voting records.

Because a full dataset for all years of interest, nor all countries of interest, was able to be created with the time and resources available during this paper's creation, a better test could not yet be performed. However, despite these disadvantages, the analyses provided in this paper offers considerable improvements over prior tests that focus mostly on the influence of IMF and World Bank loans on UN votes.

\section{Results}

Prior tests indicate that there may be a relationship between BRI countries' likelihood of voting in agreement with China and their levels of debt to china. Nevertheless, additional multivariate testes are warranted. The below regressions display how BRI countries' likelihood of voting in agreement with China is influenced by two independent variables, as reflected by these two hypotheses:

\section{Hypothesis 1: Voting Alliance}

Table 4: Regression of Voting with China and CFR Debt to China index

\begin{tabular}{l|l|l|l|l|l|l} 
probchinaagree & Coef. & Std. Err. & $\mathrm{Z}$ & $\mathrm{P}>|\mathrm{z}|$ & \multicolumn{2}{|l}{ [95\% Conf. Interval] } \\
\hline debtratio & 0.469068 & 0.1548811 & 3.03 & 0.002 & 0.1655066 & 0.772694 \\
\hline _cons & 0.6300052 & 0.0434636 & 14.49 & 0.000 & 0.544818 & 0.7151923
\end{tabular}

To test the first hypothesis, that the higher a BRI country's debt to China as a ratio of their GDP, the more likely BRI partner countries are to vote the same way as China, the variable "debtratio" had to be created. This regression shows a positive coefficient for "debtratio". To interpret the "debtratio" coefficient in terms of Hypothesis 1, it appears that for every $100 \%$ 
increase in the CFR Debt to China ratio as a percent of GDP, there is a $46.9068 \%$ increased probability that country will vote in agreement with China in the UN on human rights resolutions. The p-value of 0.002 is very small, much lower than the common significance level of alpha $=0.05$. Therefore, the "debtratio" variable is highly statistically significant. This is consistent with Hypothesis 1 and suggests that the CFR Debt to China ratio as a percent of GDP is a strong positive predicter of a BRI countries' probability of voting in agreement with China. This data supports the overarching theory, based on prior studies, that development aid is a compelling indicator for voting alliance.

\section{Hypothesis 2: Support for "Human Rights"}

Table 5: Regression between Voting with China and voting "yes" on Human Rights

\begin{tabular}{l|l|l|l|l|l|l} 
probchinaagree & Coef. & Std. Err. & $\mathrm{Z}$ & $\mathrm{P}>|\mathrm{z}|$ & {$[95 \%$ Conf. Interval] } \\
\hline averageyes & 0.8384739 & 0.0212854 & 39.39 & 0.000 & 0.7967552 & 0.8801925 \\
\hline _cons & 0.0726276 & 0.0167372 & 4.34 & 0.000 & 0.0398232 & 0.105432
\end{tabular}

To test the second hypothesis, that the higher a BRI country's tendency is to vote "yes" in the United Nations on resolutions advancing human rights, the less likely BRI partner countries are to vote the same way as China, the variable "averageyes" had to be created. This regression shows a positive coefficient for "averageyes", which is coded for each BRI partner country as the portion of their votes each year that were "yes" on human rights-related UN resolutions (hence, the "probability that they voted to pass a UN resolution on human rights"). To interpret the "averageyes" coefficient in terms of Hypothesis 2, it appears that for every $100 \%$ increase in the annual average "yes" votes on UN human rights resolutions, there is a $83.8479 \%$ increased probability that country will vote in agreement with China in the UN on human rights resolutions. The p-value of 0.000 is very small, much lower than the common significance level of alpha $=0.05$. Therefore, the "averageyes" variable is highly statistically significant. This is inconsistent with Hypothesis 2 and suggests that the annual average "yes" votes on UN human rights resolutions is a strong positive, not negative, predicter of a BRI countries' probability of voting in agreement with China. This data does not support the overarching theory, based on prior papers, that voting similarly to China would be indicative of voting in opposition to human rights resolutions. Rather these findings provide empirical proof of the contrary, supported by other scholarly findings that "China's [human rights] stance during the last two decades has 
moved closer to internationally accepted standards; in other words, that to some extent China has conformed to international human rights norms" (Dingding, 2009).

\section{Conclusion}

In summary, this paper's findings confirm available literature on the relationship between international development finance and soft power politics, but also provides empirical evidence that voting in alliance with China is not necessarily detrimental to the international human rights regime. Hypothesis 1 assessed the relationship between BRI countries' CFR Debt to China ratio as a percent of GDP and their probabilities of voting in agreement with China. The outcome was a moderately strong finding that development aid as a positive indicator for UN alliance. Hypothesis 2 assessed whether BRI countries' voting alliance with China was lowering the likelihood of voting "yes" on human rights resolutions. This test had a more surprising result. It found that voting in alliance with China increased the likelihood that BRI countries will vote "yes" on human rights resolutions, thus affirming the current international human rights regime.

These findings from 2001-2013 show that even prior to China's official launch of the Belt and Road Initiative, BRI countries were clearly more likely to align their votes with China as their debt to China increased. The implication of this is that unilateral development loans can be used to influence votes in the United Nations. With sovereignty issues involving Tibet, Taiwan, Hong Kong, and the South China Sea, it is no wonder why China would launch such an initiative that essentially gives them the reigns on whether or not resolutions will pass in the United Nations. However, this study also found that China itself is voting "yes" to UN resolutions more frequently on average. This is a hopeful sign that China is beginning to accept modern human rights norms.

Regarding Hypothesis 2, one might expect based on academic literature available that including voting records from both BRI and non-BRI countries will reveal a strong correlation between countries' average "yes" votes and probabilities of voting with China regardless of BRI partnership, or lack thereof. This is based on prior papers' suggestions that countries that align with China's cultural values will tend to vote in agreement with them.

In future research, the goal is to improve the datasets used for both Hypothesis 1 and Hypothesis 2 by collecting the following data for all UN General Assembly countries over the years 2001-2017: communist (or not), CFR Index of Debt to China ratios, probability of voting the same as China on UN General Assembly resolutions related to human rights, and the 
probability of "yes" votes on UN General Assembly resolutions related to human rights. One way to analyze diplomatic alignment is to see whether the domestic politics of BRI countries are ruled by the communist party.

Including all UNGA member countries would allow us to also control for BRI partnership vs. no BRI partnership. Establishing this control variable (BRI partnership) would more accurately isolate the impact of BRI partnership itself and whether countries UN votes are more likely to agree with China's vote. Moreover, adding another predicter variable (pre-BRI or after-BRI) to the current predicter variable (CFR Debt to China ratio) would more accurately evaluate whether the BRI's establishment in 2013 significantly increased BRI countries' voting alliance with China. By including pre-BRI and post-BRI for all UN countries, both those in the BRI and not, one will be able to see the counterfactual.

For Hypothesis 1, one could expect this improved test would show stronger correlations between BRI partner countries' CFR Index of Debt to China and voting alliance with China in "post-BRI" years compared to correlations in "pre-BRI" years. This is because the amount of development loans from China globally skyrocketed after the BRI was official announcement in 2013.

\section{Acknowledgements}

My sincerest gratitude goes to Dr. Aida Hozic of the Department of Political Science for mentoring this paper. Thank you for teaching me how to navigate Serbia's culture and for encouraging me to go on this trip with my father. You have been a truly wonderful person and advisor to me, and I have enjoyed getting to know you and work with you. I will always be grateful for your support in achieving even my most ambitious goals - and for knowing the right words to say when it's time to let go. You have done so much to guide me down the right path, both in life and in academia. Because of you, I have allowed myself to open my mind and explore other career opportunities that might be better suited for my interests. Though Spring 2020 did not turn out as I had hoped, I am still proud of the research that I was able to conduct, and I am hopeful that I will be able to continue learning more about international development finance in my future academic and professional career. Thank you also to the University Scholars Program for giving me the chance to connect with my roots and visit my father's home country of Serbia in May 2019. While in Serbia, I met with several government agencies and private sector investment groups to research the impact of recent Chinese-funded infrastructure projects on Serbia's economic reconstruction. During the free time that I had with my father, we drove across the country to visit centuries-old monasteries, and I had a chance to observe how the demographic landscape of the Balkans has evolved since the Yugoslav Civil Wars and World War II. I was also able to meet my 92year-old great aunt, and I will forever be thankful for those memories. 


\section{References}

Chatzky, A. \& McBride, J. (2019). China's Massive Belt and Road Initiative. Council on Foreign Relations. https://www.cfr.org/backgrounder/chinas-massive-belt-and-road-initiative

Chen, D.-D. (2009). China's Participation in the International Human Rights Regime: A State Identity Perspective. Chinese Journal of International Politics, 2(3), 399-419. doi:10.1093/cjip/pop002

Dreher, A., Nunnenkamp, P. \& Thiele, R. (2008). Does US aid buy UN general assembly votes? A disaggregated analysis. Public Choice, 136, 139-164. https://doi.org/10.1007/s11127-008-9286-x

Dreher, A. \& Sturm, J. (2012). Do the IMF and the World Bank influence voting in the UN General Assembly?. Public Choice, 151, 363-397. https://doi.org/10.1007/s11127-010-9750-2

Moyn, S. (2017). Human Rights and the Uses of History. Verso.

McInerney-Lankford, S. (2009). Human Rights and Development: A Comment on Challenges and Opportunities from a Legal Perspective. Journal of Human Rights Practice, 1(1), 51-82. https://doi.org/10.1093/jhuman/hun005

Steil, B. \& Della Rocca, B. (2019). Trace China's Growing Economic Influence. Belt and Road Tracker. Council on Foreign Relations. https://www.cfr.org/article/belt-and-road-tracker

Tsvyk, A. V., \& Tsvyk, G. I. (2019). China's Human Rights Concept and Its International Promotion. RUDN Journal of Sociology, 19(1), 20-29. doi:10.22363/2313-2272-2019-19-1-20-30 